BNWL-1076

UC-25

5

\title{
FATIGUE CRACK
}

GROWTH AND PROPAGATION

IN Zr-2.5 wt\% Nb ALLOY PRESSURE TUBING

June 1969

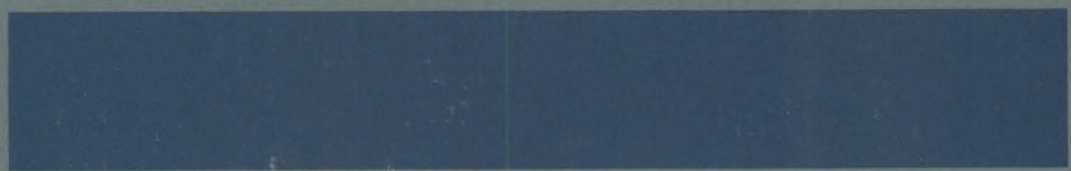

AEC RESEARCH \&

DEVELOPMENT REPORT

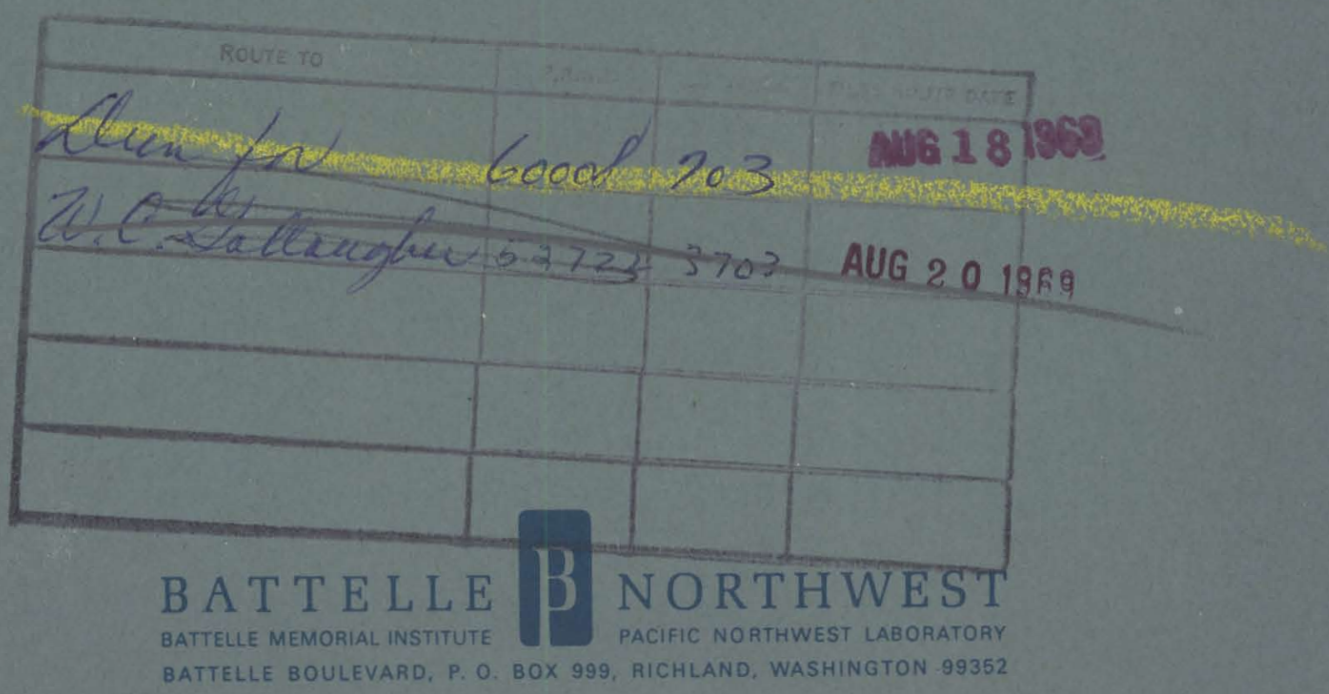




\section{LEGAL NOTICE}

This repart was prepared as an account of Government sponsored work. Neither the United States, nor the Commission, nor any person acting on behalf of the Commission:

A. Makes any warranty or representation, expressed or implied, with respect to the accuracy, completeness, or usefulness of the information contained in this report, or that the use of any information, opparatus, method, or process disclosed in this report may not infringe privately owned rights; or

B. Assumes any liabilities with respect to the use of, or for damages resulting from the use of any information, apparatus, method, or process disclosed in this report.

As used in the above, "person acting on behalf of the Commission" includes any employee or contractor of the Commission, or employee of such contractor, to the extent that such employee or contractor of the Commission, or employee of such contractor prepares, disseminates, or provides access to, any information pursuant to his employment or contract with the Commission, or his employment with such contractor.

\section{PACIFIC NORTHWEST LABORATORY \\ RICHLAND, WASHINGTON \\ operated by \\ BATTELLE MEMORIAL INSTITUTE}

for the

UNITED STATES ATOMIC ENERGY COMMISSION UNDER CONTRACT AT(45-1)-1830 


\author{
BNWL - 1076 \\ UC-25, Meta1s, \\ Ceramics, and Materials
}

FATIGUE CRACK GROWTH AND PROPAGATION

IN $2 r-2.5 w t \%$ Nb ALLOY PRESSURE TUBING 


\title{
BNWL - 1076
}

UC-25, Metals,

Ceramics, and Materials

FATIGUE CRACK GROWTH AND PROPAGATION

IN $2 r-2.5 w t \%$ ND ALLOY PRESSURE TUBING

By

\author{
P. J. Pankaskie
}

Fuels and Materials Department

Chemistry and Metallurgy Division

June 1969

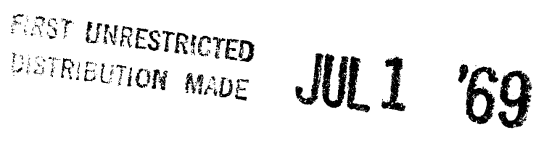

BATTELLE MEMORIAL INSTITUTE

PACIFIC NORTHWEST LABORATORY

RICHLAND, WASHINGTON 99352 
BNWL - 1.076

Printed in the United States of America Available from

Clearinghouse for Federal Scientific and Technical Information National Bureau of Standards, U.S. Department of Commerce Springfield, Virginia 22151

Price: Printed Copy $\$ 3.00 ;$ Microfiche $\$ 0.65$ 
BNWL - 1076

FATIGUE CRACK GROWTH AND PROPAGATION

IN $\mathrm{Zr}-2.5$ wt\% Nb ALLOY PRESSURE TUBING

\section{P. J. Pankaskie}

\section{ABSTRACT}

$\mathrm{Zr}-2.5 \mathrm{wt} \% \mathrm{Nb}$ alloy tubes were fatigued in the tensiontension mode by cyclic internal pressures to cause axial crack growth and unstable fractures at room temperature. Pressure cycle rates were 400 and 3000 cycles per hour. Both the cold worked and heat treated conditions, before and after hydriding (200 to $300 \mathrm{ppm} \mathrm{H}_{2}$ ), were investigated. Exploratory tests were done to determine the effect of (1) the axial length of the surface stress intensifying defect, and (2) multiple surface stress intensifying defects on fatigue crack initiation, growth and critical length at unstable fracture.

From short (less than or equal to tube wall thickness) length defects, fatigue crack initiation and growth will occur at nominal peak hoop stresses equal to or less than the estimated endurance 1 imit (about 25,000 psi). For fatigue cracks initiated at the outer diameter surface, the shape of the crack front is semicircular. The number of stress cycles required to initiate fatigue cracking at the surface is inversely proportional to the square of the surface defect length. Crack growth rates for nonhydrided tubing are proportional to $\Delta \mathrm{K}$ to the fifth power and to the fourth power after hydriding. There was a tendency for the critical crack length at unstable fracture to decrease with an increase in the number of fatigue cycles required to initiate fatigue cracking. Multiple defects may act in concert to initiate unstable fracture.

The fracture toughness of the heat treated tubing before hydriding is less than for the cold worked condition either before or after hydriding; after hydriding the fracture toughness is further reduced. In the $30 \%$ cold worked condition, 
irradiation to $10^{20} \mathrm{nvt}$ has 1 ittle effect unless hydrided; when hydrided, fracture toughness is reduced substantially. 


\section{TABLE OF CONTENTS}

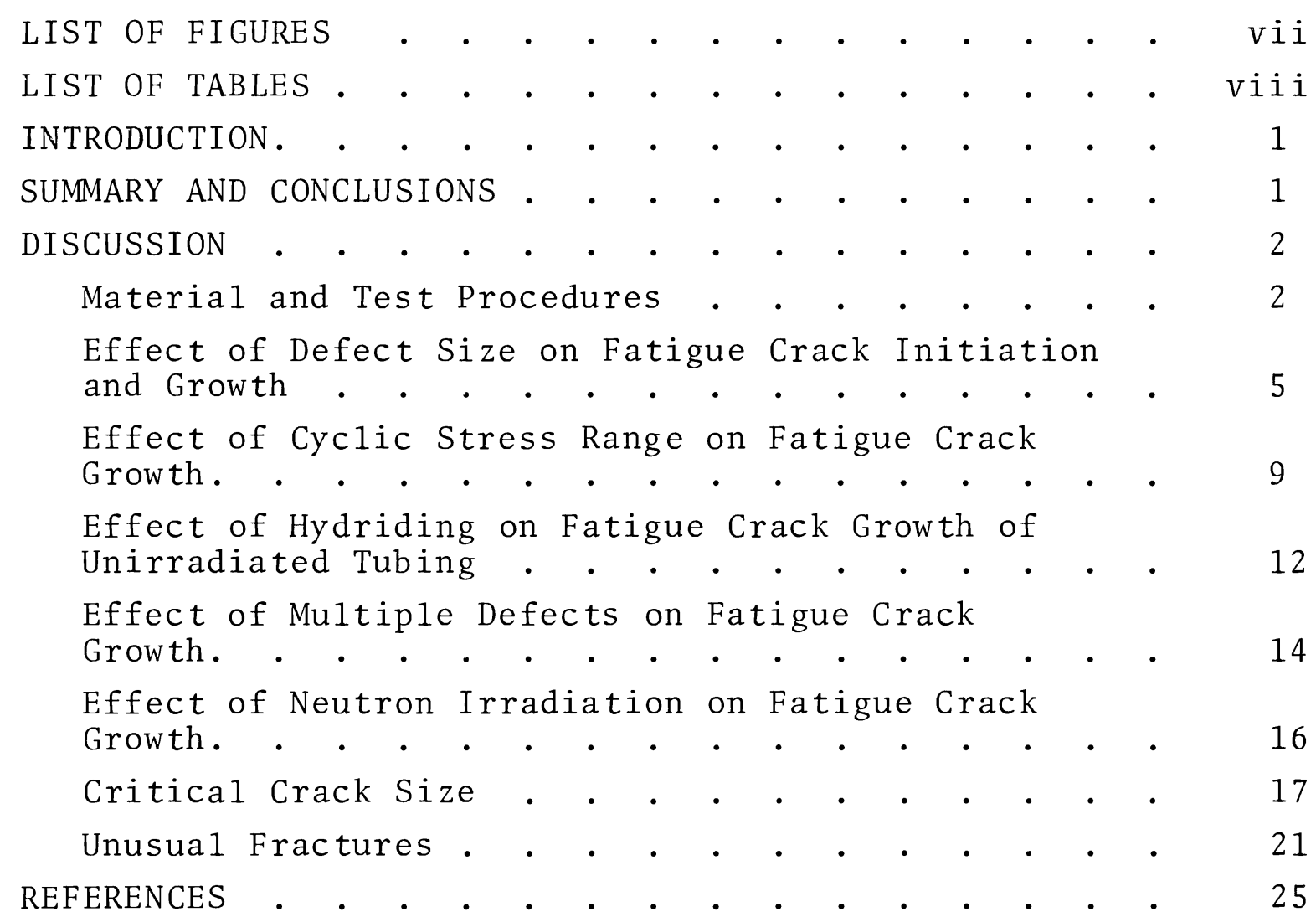




\section{LIST OF FIGURES}

1 Fatigue Crack Extension as a Function of Pressure Cycles in $\mathrm{Zr}-2.5 \mathrm{wt} \% \mathrm{Nb}$ Tubing at Room Temperature

2 Fatigue Crack Surface of a $\mathrm{Zr}-2.5$ wt: Nb Alloy Pressure Tube

3 Crack Growth Rate Versus Stress Intensity Factor for $\mathrm{Zr}-2.5 \mathrm{wt} \% \mathrm{Nb}$ Tubing

4 Crack Growth Rate Versus $\Delta \mathrm{K}$ for Hydrided $\mathrm{Zr}-2.5 \mathrm{wt} \% \mathrm{Nb}$ Tubing

$5 \quad$ Fatigue Crack Extension as a Function of Pressure Cycles in $\mathrm{Zr}-2.5 \mathrm{wt} \% \mathrm{Nb}$ Tubing with Two Parallel Axial Fatigue Cracks

6 Hoop Stress Versus Critical Crack Length for Cold Worked, Heat Treated, and Hydrided $\mathrm{Zr}-2.5 \mathrm{wt} \% \mathrm{Nb}$ Tubing

7 Tube at Top Shows Characteristic Crack Propagation in Heat Treated and Hydrided $\mathrm{Zr}-2.5$ wt: $\mathrm{Nb}$ Tubing

8 Crack Propagation Behavior in a $30 \%$ Cold Worked and Hydrided $\mathrm{Zr}-2.5$ wt $\mathrm{Nb}$ Tube

9 Crack Propagation Behavior in $\mathrm{Zr}-2.5 \mathrm{wt} \% \mathrm{Nb}$ Tube with Two Parallel Slots

10 A Circumferential Fatigue Crack at the Thread Relief in a Heat Treated and Hydrided $\mathrm{Zr}-2.5 \mathrm{wt} \% \mathrm{Nb}$ A11oy Tube 


\section{LIST OF TABLES}

1 Effect of EDM Slot Size on Fatigue Crack Growth and Propagation in $\mathrm{Zr}-2.5 \mathrm{wt} \% \mathrm{Nb}$ Alloy Tubing

2 Effect of Irradiation on Fatigue Crack

Propagation in $\mathrm{Zr}-2.5 \mathrm{wt} \% \mathrm{Nb}$ Alloy Tubing

3 Fatigue Crack Growth and Propagation Data for $\mathrm{Zr}-2.5 \mathrm{wt} \% \mathrm{Nb}$ Alloy Tubing 


\title{
FATIGUE CRACK GROWTH AND PROPAGATION
}

IN $\mathrm{Zr}-2.5 \mathrm{wt} \% \mathrm{Nb}$ ALLOY PRESSURE TUBING

\author{
P. J. Pankaskie
}

\section{INTRODUCTION}

For water cooled thermal power reactors, only the zirconium alloys possess sufficient strength at intermediate temperatures $\left(300{ }^{\circ} \mathrm{C}\right)$ and sma11 neutron capture properties to be of engineering and economic interest for use as in-core pressure tubing. The $\mathrm{Zr}-2.5 \mathrm{wt} \% \mathrm{Nb}$ alloy appears to be amenable to a combination of heat treatment and cold work that improves yield and ultimate strength over that of Zircaloy-2. For this reason, this alloy is being evaluated as a candidate for in-core pressure tubing for water cooled thermal reactors. One of the objectives of the USAEC-AECL Cooperative $\mathrm{Zr}-\mathrm{Nb}$ Pressure Tube Program is to evaluate the crack growth and propagation behavior of $\mathrm{Zr}-2.5 \mathrm{wt} \%$ $\mathrm{Nb}$ alloy pressure tubes for comparison with Zircaloy-2 pressure tubes. (1) This final report summarizes the data obtained under this program.

\section{SUMMARY AND CONCLUSIONS}

These studies have shown that fatigue cracks parallel to the tube axis can be easily produced by cyclic internal pressurization. From appropriate stress intensifiers at the inner diameter or outer diameter surface, fatigue crack initiation and growth will occur at nominal peak hoop stresses (hoop to axial stress ratio equal to 2 to 1 ) equal to or 1 ess than the estimated endurance limit (about 25,000 psi). Data are not yet available to determine whether or not the axial stress (parallel to the fatigue crack) has any significant effect on fatigue crack growth rates or critical crack sizes.

For short (equal to or less than the tube wall thickness) defects in the outer diameter surface, which initiate fatigue cracking, the crack front is semicircular with its center 
approximately at the outer diameter surface. The number of fatigue cycles required to initiate fatigue cracking is inversely related to the square of the surface length of the electrical discharge machined slot at which cracking initiates. Crack growth rates for nonhydrided tubing are proportional to $\Delta K$ to the fifth power and to $\Delta K$ to the fourth power after hydriding. Critical crack size may diminish with an increase in numbers of fatigue cycles required to initiate fatigue cracking.

The fracture toughness of cold worked $\mathrm{Zr}-2.5 \mathrm{wt} \% \mathrm{Nb}$ tubing either before or after hydriding (200 to $300 \mathrm{ppm} \mathrm{H}_{2}$ ) is greater than for heat treated tubing. For heat treated tubing, the fracture toughness after hydriding is reduced by about one-third.

The results of a few tests suggest that two or more defects may act in concert to initiate unstable fracture. More data are needed to verify and quantify the influence of multiple defects on crack growth and propagation.

In the $30 \%$ cold worked condition, neutron irradiation at an estimated flux of $10^{12} \mathrm{nv}$ and a fluence estimated at $10^{20} \mathrm{nvt}$ appeared to have little or no effect on the crack propagation characteristics of $\mathrm{Zr}-2.5 \mathrm{wt} \% \mathrm{Nb}$ alloy tubing. When tubing in the $30 \%$ cold worked condition is hydrided (200 to $300 \mathrm{ppm}$ ) and irradiated, the fracture toughness appears to decrease by about $50 \%$ or more. More data, particularly at higher fluxes and fluences, are needed to verify and quantify neutron irradiation effects.

\section{DISCUSSION}

\section{MATERIAL AND TEST PROCEDURES}

The $\mathrm{Zr}-2.5 \mathrm{wt} \% \mathrm{Nb}$ alloy used in these tests was obtained from prototypic reactor pressure tubing. The material conditions investigated were the

- Cold worked (30\% to $60 \%$ reduction in area) 
- Heat treated $\left(880^{\circ} \mathrm{C}\right.$ soak, water quench, $15 \%$ reduction in area and age $24 \mathrm{hr}$ at $500{ }^{\circ} \mathrm{C}$ )

- Both the cold worked and the heat treated material hydrided to concentrations of 200 to $300 \mathrm{ppm}$, and

- Cold worked hydrided and nonhydrided irradiated to a fluence of about $10^{20} \mathrm{nvt}$.

Al1 test specimens were short tubes cut from prototypic reactor pressure tubing. Most of the test specimens were nominally 16 in. long, 2.1 in. ID, wall thicknesses ranging from 0.140 to $0.180 \mathrm{in.}$, and inside diameter to wall thickness $(D / t)$ ratios of 12 to 15 . One specimen was 3.25 in. ID, wall thickness of $0.18 \mathrm{in.}$, and a $\mathrm{D} / \mathrm{t}$ ratio of 18 . Three tubes with an inside diameter of 4.07 in., wall thickness of $0.095 \mathrm{in.}$, and a $D / t$ ratio of about 43 were hydrided by an electrolytic method to concentration levels of nominally $300 \mathrm{ppm}$. This tubing was supplied and the hydriding done by the Chalk River National Laboratory.

In the tests on unirradiated tubing, a simulated surface flaw was made at the tube surface to produce a point of stress concentration during cyclic internal pressurization of the test specimen to initiate a fatigue crack. The surface flaw was formed by cutting a small slot into the outer or inner surface using electrical discharge machining (EDM) methods. In all cases the EDM electrode was 5 mils thick and produced a slot nominally 7 to $8 \mathrm{mils}$ wide. In one instance, the EDM slot was about 15 mils wide; in machining a 0.025 in. radius EDM slot, the $0.005 \mathrm{in}$. thick by $0.025 \mathrm{in}$. wide electrode tended to vibrate causing the relatively large width of the slot. No such difficulties were encountered with the larger electrodes. In most cases, the shape of the EDM slot was semicircular with the center of the semicircle at the outer surface of the tubular test piece. In one test, the EDM slot was rectangular, 
and in one test a semicircular EDM slot was made from the inside of the tube with the center of the semicircle at the inner surface. In all cases the EDM slot was parallel to the tube axis and located at the mid-length and the thinnest wall area. The radii of the semicircular EDM slots ranged from $15 \%$ of the tube wall thickness to a maximum of about $80 \%$.

Four tests were done on tubes with two EDM slots paralle1 to each other and to the tube axis cut into the outside diameter surface. The EDM slot radii were all nominally 0.15 in. and the circumferential spacing between parallel EDM slots was $3 / 8$ in. Axial center-to-center spacing was varied from 0 to 0.9 in.

There were four $30 \%$ cold worked tubes which were irradiated in a standard fuel channel in the Plutonium Recycle Test Reactor. The fast flux was estimated to be about $10^{12} \mathrm{nv}$ and the fluence estimated to be $10^{20}$ nvt. For all specimens a $1 / 8$ in. wide slot was milled into the outside surface prior to irradiation to a depth equivalent to $80 \%$ of the tube wall thickness. In two specimens, one hydrided and one unhydrided, the slot length in each was $1 / 2$ in.; in the other two, one hydrided and one unhydrided, the slot lengths were $1-1 / 2$ in. A11 four tubular test specimens were prepared for postirradiation testing prior to insertion in the PRTR.

Stress cycling was done by cyclic internal pressurization of the tubular test piece. The minimum and peak cyclic pressures were adjusted to produce the desired minimum and peak hoop stresses in a tension-tension mode. Except for end caps, which seal the tubular test piece, there were no external axial or circumferential restraints and a nominal 2 to 1 hoop to axial stress ratio was maintained throughout each pressure cycle of the entire test. Al1 tests were done at room temperature. 
The rate of pressure cycling ranged from about 400 cycles per hour to a high of 3000 per hour. In each test, however, the cycle rate was held constant throughout the entire test. In the majority of the tests, pressure cycling was continued until the fatigue crack grew to critical size. In a few tests, pressure cycling was stopped before the crack had grown to critical size, and the internal pressure was quickly and steadily increased until unstable fracture occurred. A11 fatigue crack lengths were measured at the outer surface of the tubular test piece. Crack lengths were measured to the nearest 0.005 in.

\section{EFFECT OF DEFECT SIZE ON FATIGUE CRACK INITIATION AND GROWTH}

In one series of five tests, the nominal cyclic hoop stress range, minimum and peak stresses, and the cycle rate were constant in each of the five tests. For these tests the stress range, $\Delta \sigma_{\theta}, *$ was 21,500 psi, and the cycle rate was about 400 cycles per hour. In each tubular test piece, one semicircular EDM slot was machined into the outer surface. For all tests the nominal peak cyclic hoop stress was 23,000 psi, which is believed to be slightly below the endurance limits for this a11oy. (For Zircaloy-2, O'Donnel and Langer (1) determined the endurance limit to be about $25,000 \mathrm{psi}$. This alloy is somewhat stronger than Zircaloy-2, and the endurance limit may be slightly greater.) The radius of the EDM slot was varied from 0.025 in. to about 0.125 in.

The data from these tests are listed in Table 1 and shown graphically in Figure 1 .

In Test 26, the EDM slot width was about twice that for a11 other EDM slots and was caused by vibration of the $0.005 \mathrm{in.}$ thick by 0.025 in. wide electrode.

$\begin{aligned} * \Delta \sigma_{\theta}= & \text { peak hoop stress minus minimum hoop stress in each } \\ & \text { pressure cycle. }\end{aligned}$ 
TABLE 1. Effect of EDM Slot Size on Fatigue Crack Growth and Propagation in $2 r-2.5$ wt\% Nb Alloy Tubing

\begin{tabular}{|c|c|c|c|c|c|c|c|}
\hline $\begin{array}{c}\text { Test } \\
\text { Identity } \\
\end{array}$ & $\begin{array}{l}\text { EDM Slot } \\
\text { Radius, } \\
\text { in. }\end{array}$ & $\begin{array}{c}\text { Cycles } \\
\text { to Crack } \\
\text { Initia- } \\
\text { tion } \\
\end{array}$ & $\begin{array}{c}\text { Cycles } \\
\text { to } \\
\text { Leak } \\
\end{array}$ & $\begin{array}{c}\text { Leak } \\
\text { Crack } \\
\text { Length, } \\
\text { in. } \\
\end{array}$ & $\begin{array}{c}\text { Cycles } \\
\text { to } \\
\text { Failure } \\
\end{array}$ & $\begin{array}{c}\text { Critical } \\
\text { Crack } \\
\text { Length, } \\
\text { in. } \\
\end{array}$ & $\begin{array}{c}\text { Cycles } \\
\text { from } \\
\text { Leak to } \\
\text { Failure } \\
\end{array}$ \\
\hline 9 & 0.125 & $\sim 5,300$ & 9,695 & 0.43 & 18,628 & 1.37 & 8,933 \\
\hline 11 & 0.100 & $\sim 10,000$ & 17,400 & 0.42 & 24,960 & 1.31 & 7,540 \\
\hline 22 & 0.075 & $\sim 15,000$ & 28,400 & 0.41 & 35,554 & 1.08 & 7,154 \\
\hline $22 \mathrm{~A}$ & 0.050 & $\sim 22,000$ & 40,550 & 0.41 & 47,199 & 0.95 & 6,649 \\
\hline 26 & 0.027 & ح94,000 & 114,900 & 0.38 & 121,550 & 1.05 & 6,650 \\
\hline
\end{tabular}

In Figure 1, the length of the crack initiating EDM slot is plotted on the ordinate at the number of cycles between the last surface inspection prior to and the first surface inspection subsequent to the occurrence of surface cracking. This number of cycles (determined within a few thousand cycles at most) is taken as the point at which fatigue cracking was initiated. Microscopic examination of the fractured surface of several of these test specimens suggests that, for the semicircular EDM slot with its center at the outer diameter surface, cracking originates at the outer diameter surface ends of the EDM slots. It is interesting to note that in tubing, the fatigue crack tends to assume a semicircular shape for stress concentrating defects located in the outer diameter surface. The photograph in Figure 2 shows this semicircular shape even though the EDM slot in the outside diameter surface was rectangular. This semicircular shape seems to be retained even as the crack grows toward critical size.

For this test series, it appears that the onset of fatigue cracking ( $v$ isible through a microscope at $40 \mathrm{X}$ ) is signalled by the appearance of surface cracking. Using this criterion, it then appears that the number of stress cycles necessary to initiate fatigue cracking is inversely proportional to the square 


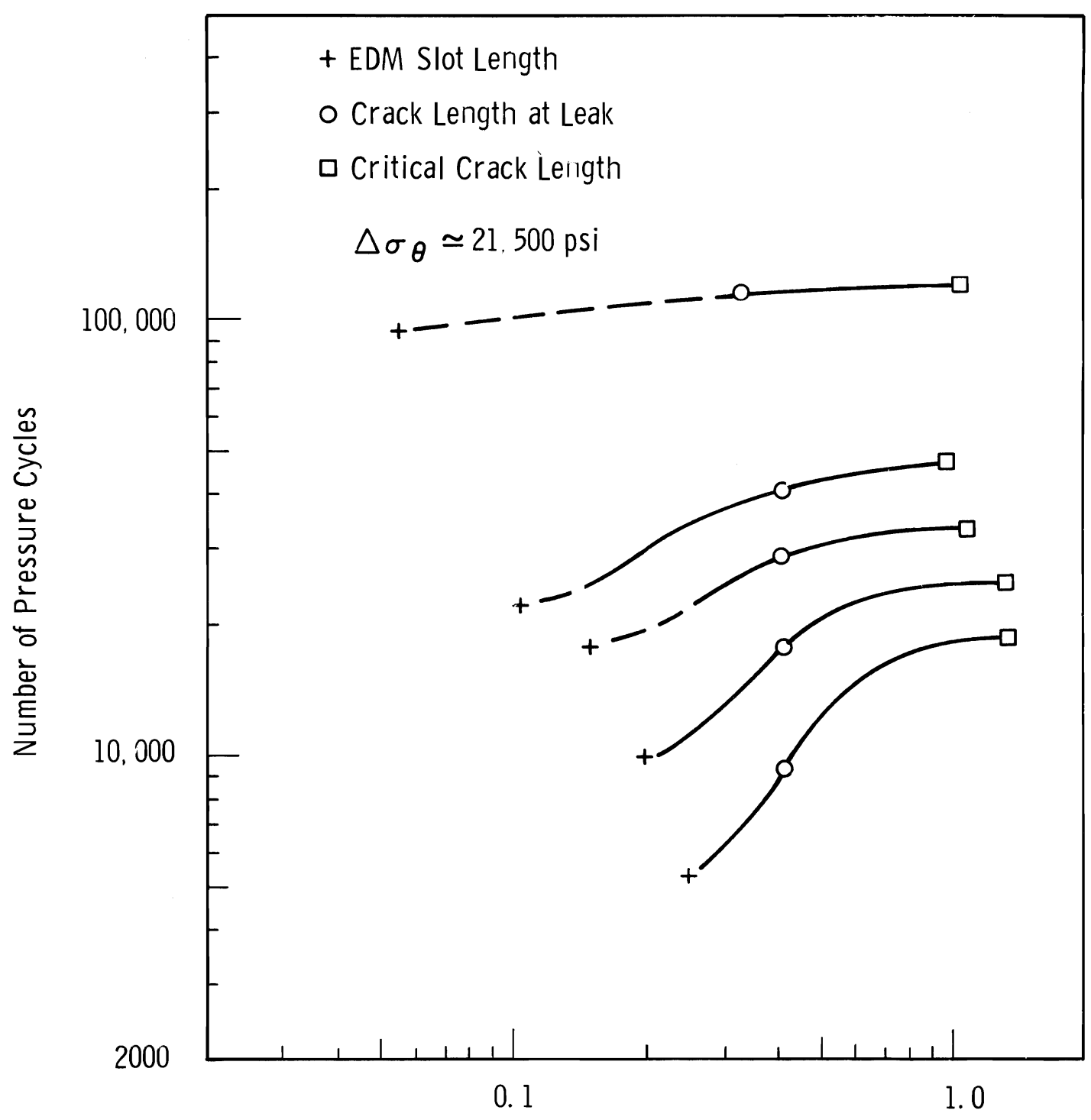

Fatigue Crack Length - Inches

Neg $0683127-4$

FIGURE 1. Fatigue Crack Extension as a Function of Pressure cycles in Zr-2.5 wt\% Nb Tubing at Room Temperature 
Fast Fracture Surface

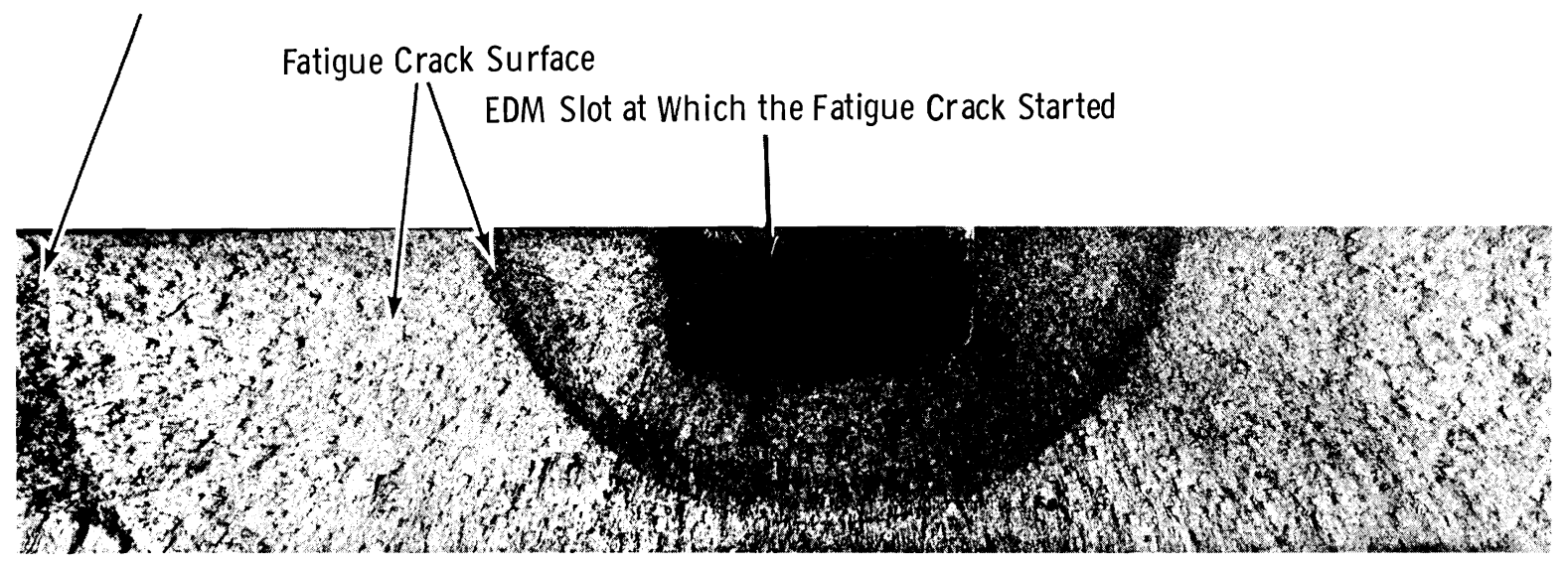

Neg $0683127-10$

FIGURE 2. Fatigue Crack Surface of a Zr-2.5 wt\% Nb AZZoy Pressure Tube

of the surface length of the EDM slot. From Figure 1, one can determine this proportionality as

$$
\mathrm{N}_{\mathrm{i}} \sim \frac{1}{(2 r)^{2}}
$$

where

$$
\begin{aligned}
N_{i}= & \text { number of cycles required to initiate fatigue cracking } \\
r= & \text { radius of the EDM slot with its center at the outer } \\
& \text { diameter surface. }
\end{aligned}
$$

Further examination of the data in Table 1 shows that except for Test 26, the crack length at which leaking occurs is about 0.42 in. For Test 26 , the tube wall thickness was nominally 0.17 in. Considering the ratio of crack length at the outer diameter surface to the nominal tube wall thickness, one finds this ratio to be very nearly constant. The crack length at which the tube leaks appears to be essentially a function of tube geometry. Once the fatigue crack penetrates the tube wall, the tube will leak (ooze) at about one-half (about 9,000 to $12,000 \mathrm{psi}$ ) the nominal peak cyclic hoop stress. 
For these tests (Table 1), it was found that the critical crack length for unstable fracture under cyclic stress tends to decrease in those tests where a greater number of cycles are required to initiate fatigue cracking. Here again, Test 26 seems to be somewhat of an exception. Crack growth rates, however, do not seem to be significantly affected (see Figure 3 ). While one is inclined to conclude that prior fatigue may adversely affect the critical crack size for unstable fracture, the observed variations may be due in part to material scatter. Perhaps the most significant observation one can make from these tests is that a pressure tube in this material state is likely to leak sometime before it fails catastrophica11y.

\section{EFFECT OF CYCLIC STRESS RANGE ON FATIGUE CRACK GROWTH}

In addition to the above series of five tests, several tests were done at various cyclic stress ranges. Crack growth data was obtained from all test specimens except from the irradiated test specimens. In all of these tests, the cycle rate was about 400 cycles per hour. The purpose of these tests was primarily to provide test specimens for unstable crack propagation tests. One test, however, is of special interest in that the fatigue crack initiating defect was cut into the inner diameter surface from inside the tubular test specimen. In this specimen, the EDM slot radius was nominally $0.125 \mathrm{in}$. and the nominal cyclic hoop stress range was 18,500 psi. An accelerometer was attached to the tube in an attempt to detect the onset of fatigue cracking. While the accelerometer was not sensitive enough to detect the onset of the fatigue cracking, it readily signalled leakage as the crack grew through the tube wa11. When leakage occurred, the fatigue crack at the outer diameter surface measured approximately 0.12 in. Under cyclic conditions the crack grew to a critical length (outer diameter 


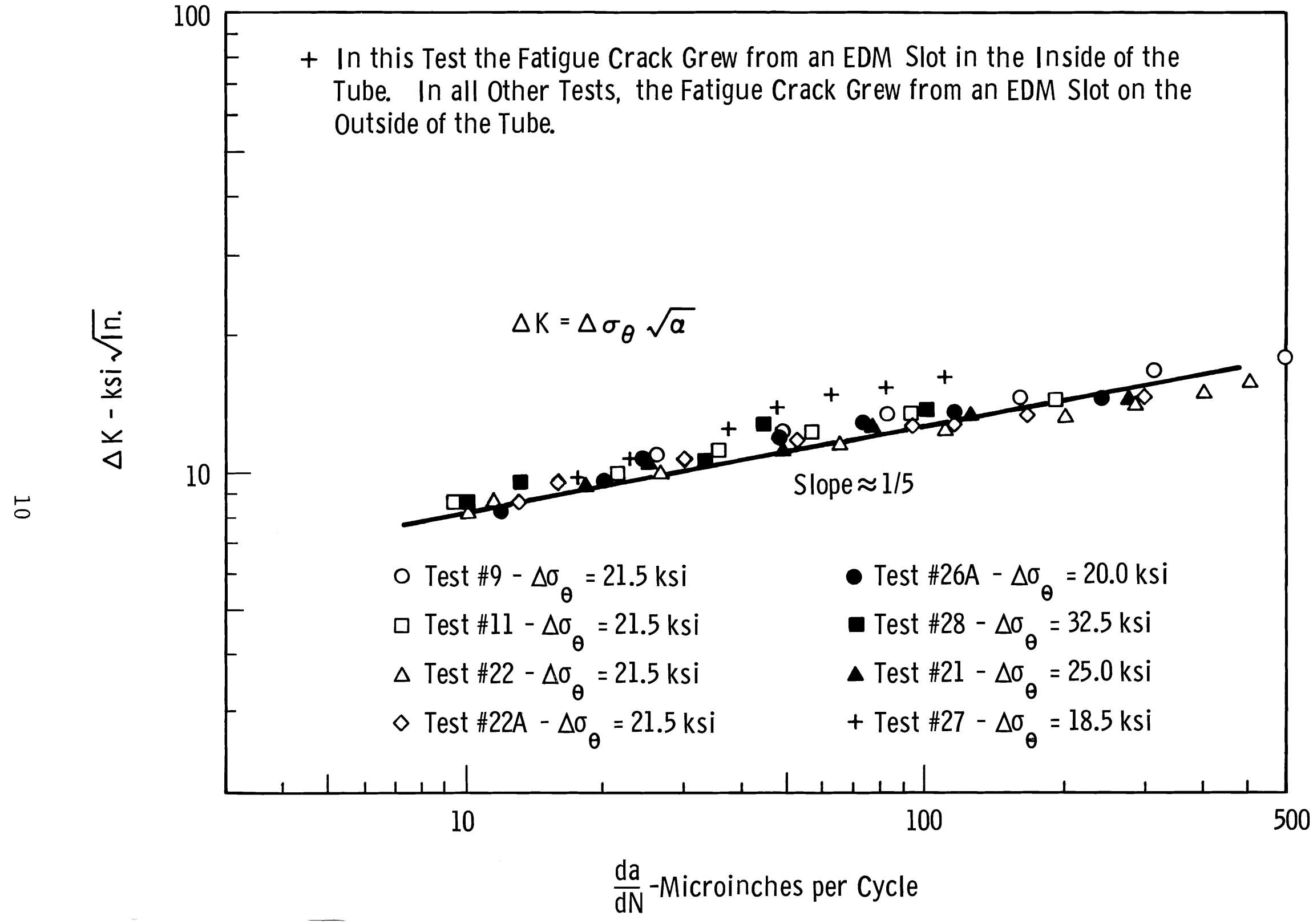


measurement) of about 2.05 in. This critical size appears to be somewhat greater than for tests wherein fatigue cracking initiated from an EDM slot at the outer diameter surface.

For all of the aforementioned tests, the crack growth rates were determined. These data were plotted as a function of stress intensity factor, $\Delta K$ (see Figure 3 ). For these data $\Delta \mathrm{K}$ was calculated from:

$$
\Delta K=\Delta \sigma_{\theta} \sqrt{\mathrm{a}}
$$

where

$$
\begin{aligned}
\Delta \sigma_{\theta}= & \text { nominal hoop stress range, } \mathrm{ksi} \\
\mathrm{a}= & \text { the one-half crack length measured at the outer } \\
& \text { diameter surface. }
\end{aligned}
$$

This is the standard equation for a center notched infinitely large plate subjected to uniform normal body stresses. (2) In tubing, body stresses normally are biaxial, and in these tests the nominal hoop-to-axial stress ratio was 2 to 1 . In thick wall tubing, there is a small stress gradient across the tube wall; at the inner diameter surface the fiber stress is greatest. Because of this gradient, $\Delta K$ varies from a minimum at the outer surface to a maximum at the inner surface. In spite of these differences, this equation seems to fit the data as well as any that are analytically tractable. $(3,4)$

For the aforementioned tests, the curve of crack growth rates versus $\Delta K$ is shown in Figure 3 . For all but one test, all data appears to fit a straight line with a slope of about one-fifth on a log-log plot. For the test wherein the fatigue crack started at an EDM slot in the inner surface, the slope of the growth rate versus $\Delta K$ curves appears to be about onefourth or less. Part of this difference may be due to the shape of the fatigue crack and the way crack length measurements are obtained. As was seen in Figure 2, the fatigue crack front 
BNWL - 1076

is semicircular. Crack length measurements are made at the outer diameter surface. Hence, when the fatigue crack starts at an EDM slot in the outer diameter surface, the measured crack length for a given growth rate is larger than it is when the fatigue crack starts at an EDM slot in the inner diameter surface. The effect of crack origin diminishes as the crack radius becomes large. Some of the difference may be due to the fact that the fiber stress is greatest at the inner diameter surface.

According to Paris (5) the crack growth rate is a function of $\Delta \mathrm{K}$ to the fourth power. If an average crack length (i.e., arithmetic average of the crack length at the inner and outer surface) is used instead of the outer surface length, the slope of the curve in Figure 3 would tend toward a value of onefourth. This suggests that in these tests, the axial stress had 1ittle effect on fatigue crack growth.

\section{EFFECT OF HYDRIDING ON FATIGUE CRACK GROWTH OF UNIRRADIATED}

TUB I NG

Six tests were done on hydrided tubing. Tubing in the cold worked and the heat treated conditions was hydrided at about $425{ }^{\circ} \mathrm{C}$ to saturation levels (200 to $\left.300 \mathrm{ppm} \mathrm{H}_{2}\right)$. A semicircular EDM slot with a radius of about 0.125 in. was cut into the outer diameter surface of each of the test specimens. For these tests the cycle rate was about 3000 cycles per hour.

Unstable fracture unde: cyclic conditions occurred only in the heat treated and hydrided tubes. In several of the heat treated and hydrided tubes, unstable fracture occurred within about 2000 pressure cycles, and crack growth data could not be obtained. The results of these tests are shown in Figure 4 as a curve of crack growth rate versus $\Delta \mathrm{K}$. After hydriding, the slope of the $\Delta \mathrm{K}$-growth curve is about one-fourth. Compared to the nonhydrided material, hydriding appears to have the effect 
BNWL-1076

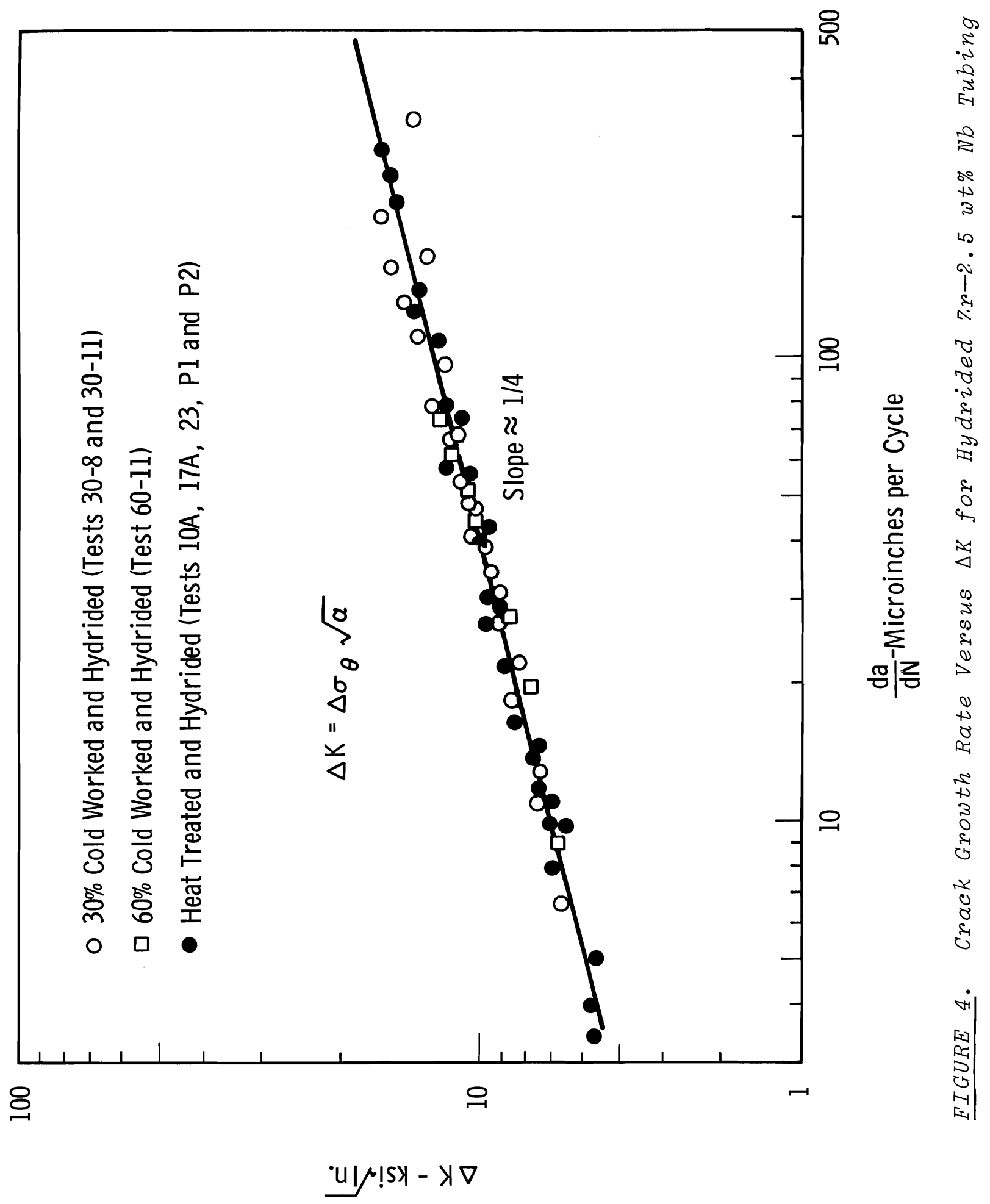


BNWL- 1076

of diminishing crack growth rates. The rather large differences in cycle rates may have some effect on crack growth rates.

\section{EFFECT OF MULTIPLE DEFECTS ON FATIGUE CRACK GROWTH}

Four tests were done on tubes with two parallel EDM slots cut into the outer diameter surface. The purpose was to determine whether or not there was a serious adverse effect of clustered defects on the critical length at unstable fracture. In all four tests, the two EDM slots were parallel to the tube axis, separated circumferentially by $3 / 8$ in., and had radii of about 0.15 in. Axial center-to-center spacing of the EDM slots was varied from 0 to 0.9 in. Pressure cycle rate for these tests was about 3000 cycles per hour.

Curves of crack extension versus pressure cycles for each of the tests are shown in Figure 5. For the test (Test 30) where the axial spacing was zero, crack growth occurred mostly from one EDM slot only. While crack growth did occur from the second EDM slot throughout the test, its total growth was limited to about 0.40 in. Hence, the crack growth behavior was essentially that of a single fatigue crack. Leaking occurred very early in the test and before surface fatigue cracking was observed. Subsequent examination revealed that the EDM slot was cut nearly through the tube wall.

As the axial spacing is increased to about 0.6 in., the number of cycles to unstable fracture and the critical crack length tend to decrease. When the axial spacing was increased to 0.9 in. there was no apparent reduction in cycles to failure, but the critical crack length appears to have been reduced. In each of the three tests, crack growth from each of the two EDM slots was comparable.

This test series suggests that when the tips of two or more fatigue cracks are near, some interaction may occur. More experiments, however, are needed to verify and quantify such effects. 


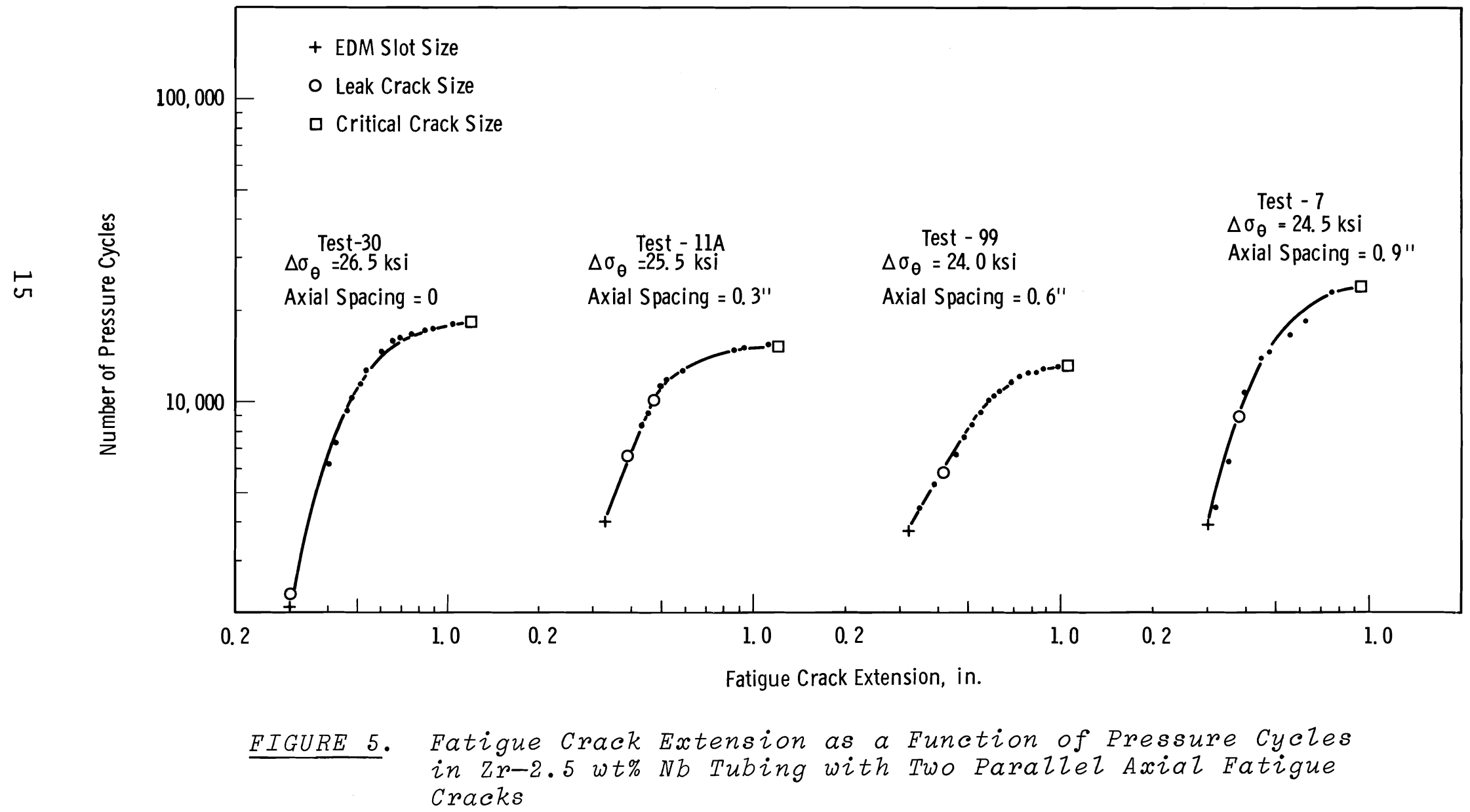


EFFECT OF NEUTRON IRRADIATION ON FATIGUE CRACK GROWTH

Four tests were done on irradiated tubing. All specimens were in cold worked condition. Two of the four specimens were hydrided prior to irradiation, and two were unhydrided. After irradiation to a fluence of about $10^{20} \mathrm{nvt}$ at a fast flux (E $>1 \mathrm{MeV}$ ) of an estimated $10^{12} \mathrm{nv}$, the four tubes were fatigued in the same manner as all other test specimens. Pressure cycle rates were about 400 cycles per hour. The results are tabulated in Table 2 .

TABLE 2. Effect of Irradiation on Fatigue Crack Propagation in Zr-2. 5 wt\% Nb AlZoy Tubing

\begin{tabular}{|c|c|c|c|c|c|c|}
\hline $\begin{array}{c}\text { Test } \\
\text { Identity } \\
\end{array}$ & Hydrided & $\begin{array}{l}\text { Slot } \\
\text { Length, } \\
\text { in. } \\
\end{array}$ & $\begin{array}{r}\Delta \sigma_{\theta}, \\
\mathrm{ks} 1\end{array}$ & $\begin{array}{c}\text { Cycles } \\
\text { to } \\
\text { Leak } \\
\end{array}$ & $\begin{array}{c}\text { Cycles } \\
\text { to } \\
\text { Fail } \\
\end{array}$ & $\begin{array}{l}\text { Crack Length } \\
\text { at Failure, } \\
\text { in. }\end{array}$ \\
\hline $\mathrm{K}-\mathrm{A}$ & None & $1 / 2$ & 30.0 & 1350 & 1,428 & $1 / 2$ \\
\hline$K-B$ & $200-300 \mathrm{ppm}$ & $1 / 2$ & 14.5 & 384 & 13,000 & $1 / 2$ \\
\hline $\mathrm{K}-\mathrm{C}$ & None & $1-1 / 2$ & 18.0 & 1523 & 2,468 & $1-1 / 2$ \\
\hline$K-D$ & 200-300 ppm & $1-1 / 2$ & 11.5 & - - & 5 & $1-1 / 2$ \\
\hline
\end{tabular}

The data shown in Table 2 provide essentially no information as to the effect of irradiation on fatigue crack growth behavior. In three of the four specimens, a crack was initiated in the web of the $1 / 8$ in. wide milled slot. These tests were done under water (about $4 \mathrm{ft}$ of water shielding), and the crack size in the web area is not easily seen. Hence, no measurements were obtainable until the crack could grow beyond the ends of the milled slot. Unfortunately, in all four tests, the critical crack length was very nearly the same as the milled slot length. In two specimens ( $K-A$ and $K-C$ ) failure occurred within about 1000 cycles after a leaking crack formed in the web of the milled slot even though there was a large difference in milled slot lengths. Neither of these specimens was hydrided. One of the hydrided specimens (K-B), however, sustained nearly 13,000 cycles without the fatigue crack growing at the outer surface beyond the ends of the milled slot. 


\section{CRITICAL CRACK SIZE}

One of the main purposes of all tests was to obtain critical crack size data. The data that were obtained are shown graphically in Figure 6 and 1 isted in Table 3 .

Of a11 material conditions investigated, the heat treated condition after hydriding (200 to $300 \mathrm{ppm}_{2}$ ) possesses the lowest fracture toughness (see Figure 6). In a11 of these specimens, fracture occurs essentially in the plane strain mode. A typical fracture is shown in the upper photograph of Figure 7 .

The heat treated condition in the absence of hydriding fails in essentially the same manner as it does after hydriding. Fracture toughness is, however, roughly $50 \%$ greater than after hydriding. There is, however, appreciable scatter in these data. Some of these tests specimens experience a rather large number of fatigue cycles prior to unstable fracture. As seen in Table 1 and Figure 1 , the critical crack length tends to decrease with increasing amounts of prior fatigue damage.

Tubing in the cold worked condition either before or after hydriding possesses good fracture toughness. The curve of hoop stress versus crack length is not included in Figure 6 because there was no unstable crack propagation from the ends of the fatigue cracks. In all but one test, ductile tearing was limited to that needed to relieve the pressure in the tube. A typical fracture of cold worked tubing before or after hydriding is shown in the lower photograph of Figure 7 .

Irradiation at a neutron flux estimated to be $10^{12} \mathrm{nv}$ $(\mathrm{E}>1 \mathrm{MeV})$ and to a fluence of about $10^{20}$ nvt does not appear to alter significantly the fracture toughness of tubing in the nonhydrided and $30 \%$ cold worked condition. Unirradiated and hydrided tubing in the $30 \%$ and $60 \%$ cold worked condition has good fracture toughness as evidenced by the fact that no 


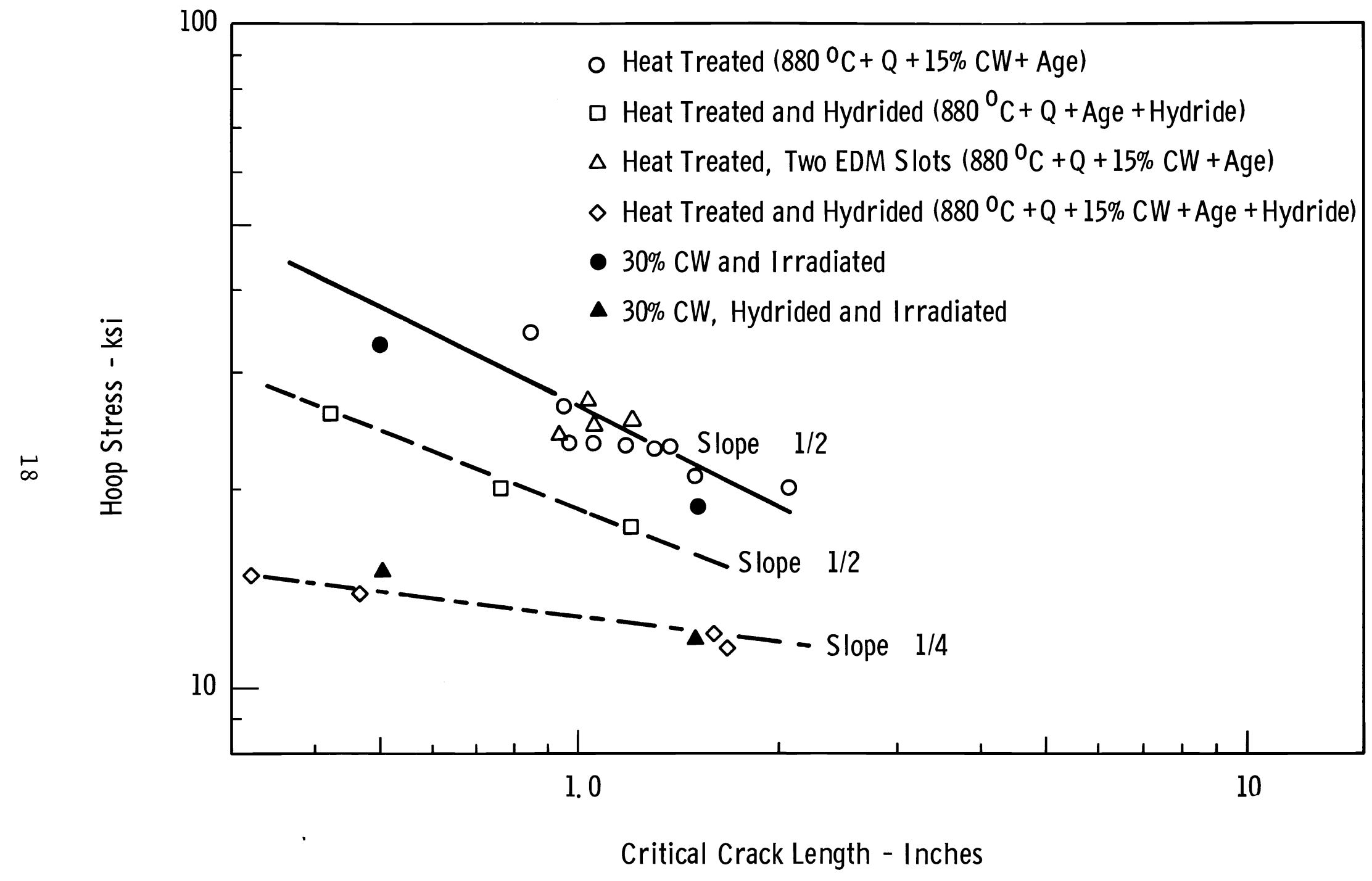

FIGURE 6. Hoop Stress Versus Critical Crack Length for Cold Worked, Heat Treated, and Hydrided $Z r-2.5$ wt\% Nb Tubing 
BNWL -1076

TABLE 3. Fatigue Crack Growth and Propagation Data for
Zr-2.5 wt\% Nb AlZoy Tubing

\begin{tabular}{|c|c|c|c|c|c|c|c|c|c|c|c|}
\hline $\begin{array}{c}\text { Test } \\
\text { Identity } \\
\end{array}$ & & $\begin{array}{l}\text { Material } \\
\text { Condition }\end{array}$ & $\begin{array}{c}\text { Nominal } \\
\text { Peak Hoop } \\
\text { Stress, ksi } \\
\end{array}$ & $\begin{array}{l}\Delta \sigma_{\theta}, \\
\mathrm{ksi}\end{array}$ & $\begin{array}{c}\text { Critical } \\
\text { Crack } \\
\text { Length, } \\
\quad \text { in. } \\
\end{array}$ & $\begin{array}{c}\text { Cycles } \\
\text { to Initiate } \\
\text { Cracking } \\
\end{array}$ & $\begin{array}{l}\text { Cycles } \\
\text { to Leak }\end{array}$ & $\begin{array}{l}\text { Leak } \\
\text { Crack } \\
\text { Length, } \\
\quad \text { in. } \\
\end{array}$ & 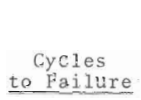 & $\mathrm{R} / \mathrm{t}$ & $\begin{array}{l}\text { Cycles } \\
\text { Ratio, } \\
\text { hr } \\
\end{array}$ \\
\hline 9 & & $\begin{array}{l}\text { Heat treated } \\
+15 \% \mathrm{CW} \\
+ \text { Aged }\end{array}$ & 23.0 & 21.5 & 1.37 & $\approx 5,300$ & 9,695 & 0.43 & 18,628 & 7 & 400 \\
\hline 11 & & & 23.0 & 21.5 & 1.31 & $\sim 10,000$ & 17,400 & 0.42 & 24,960 & 7 & 400 \\
\hline 22 & & & 23.0 & 21.5 & 1.08 & 215,000 & 28,400 & 0.41 & 35,554 & 7 & 400 \\
\hline $22 \mathrm{~A}$ & & & 23.0 & 21.5 & 0.95 & $\sim 22,000$ & 40,550 & 0.41 & 47,199 & 7 & 400 \\
\hline 26 & & & 23.0 & 21.5 & 1.05 & $\sim 94,000$ & 114,900 & 0.38 & 121,550 & 6 & 400 \\
\hline 27 & & & 20.0 & 19.5 & 2.05 & - - & ح14, 600 & $\begin{array}{l}0.12 \\
\text { (EDM slot } \\
\text { in ID surface) }\end{array}$ & 31,131 & 7 & 400 \\
\hline 21 & & & 26.5 & 26.0 & 0.95 & $\sim 2,000$ & $\sim 3,000$ & 0.38 & 9,550 & 6 & 400 \\
\hline $26 \mathrm{~A}$ & & & 21.0 & 20.5 & 1.5 & -.. & $\ldots$ & $\cdots$ & 1,550 & 7 & 400 \\
\hline $30 *$ & & & 28.0 & 26.5 & 1.25 & $\ldots$ & 2,250 & 0.33 & 18,000 & 6 & 400 \\
\hline $11 A^{*}$. & & & 27.0 & 25.5 & 1.21 & 26,600 & $\sim 10,000$ & 0.47 & 15,120 & 7 & 400 \\
\hline $99^{*}$ & & & 25.0 & 23.5 & 1.05 & 24,200 & 5,800 & 0.43 & 13,420 & 7 & 400 \\
\hline $7 *$ & & & 25.5 & 24.0 & 0.52 & $\sim 4,000$ & 6,250 & 0.38 & 24,300 & 7 & 400 \\
\hline 28 & & 1 & 34.0 & 22.5 & 0.85 & 290,000 & 129,000 & 0.46 & $\begin{array}{l}\text { Static } \\
\text { Failure }\end{array}$ & 7 & 400 \\
\hline $30-11 S R$ & & $30 \% \mathrm{CW}$ & 58.0 & 22.0 & $0.68 / 0.43$ & $\cdots$ & $\cdots$ & - - & $\begin{array}{l}\text { Static } \\
\text { Failure }\end{array}$ & 7 & 400 \\
\hline $\mathrm{K}-\mathrm{A}$ & & $\begin{array}{ll} & 30 \% \mathrm{CW} \\
+\quad \text { Irradiated }\end{array}$ & 31.0 & 30.0 & $1 / 2$ & $\ldots$ & 1,350 & $-\cdot$ & 1,428 & 7 & 400 \\
\hline $\mathrm{K}-\mathrm{C}$ & & 1 & 19.0 & 18.0 & $11 / 2$ & - - & 1,543 & $\ldots$ & 2,468 & 7 & 400 \\
\hline 8 & & $\begin{array}{l}\text { Heat treated } \\
+15 \% \mathrm{CW} \\
+\mathrm{Aged} \text { and } \\
\text { Hydrided }\end{array}$ & 15.0 & 15.0 & 0.25 & & ailed in first & st few cycles.) & & 7 & 3,000 \\
\hline 23 & & 1 & 14.0 & 12.5 & 0.46 & $<13,000$ & 23,800 & $\ldots$ & 25,830 & 7 & 3,000 \\
\hline p-1 & & & 12.5 & 11.0 & 1.61 & $\sim 635,000$ & ... & $\ldots$ & 685,640 & 10 & 3,000 \\
\hline $\mathrm{P}-2$ & & & 11.5 & 11.0 & 1.68 & $\sim 50,000$ & $\begin{array}{c}120,000 \\
\text { (estinated) }\end{array}$ & -- & 176,000 & 10 & 10,000 \\
\hline $10 \mathrm{~A}$ & & $\begin{array}{l}\text { Heat treated } \\
+ \text { Aged } \\
+ \text { Hydrided }\end{array}$ & 17.4 & 16.0 & 1.2 & 215,000 & 50,180 & - - & 79,120 & 7 & \\
\hline $17 \mathrm{~A}$ & & & 20.0 & 19.5 & 0.76 & $\sim 10,000$ & 18,500 & $\cdots$ & 49,680 & 7 & \\
\hline $2 I \mathrm{~A}$ & & 1 & 26.0 & 23.5 & 0.42 & $\sim 3,700$ & 6,470 & $\cdots$ & 6,522 & 7 & \\
\hline $30-8$ & $30 \%$ & $\mathrm{CW}$ and Hydrided & 17.0 & 14.5 & 3.05 & $\sim 40,000$ & 53,850 & $\cdots$ & $=-$ & 7 & $\begin{array}{c}\text { Crack } \\
\text { Arrested }\end{array}$ \\
\hline $30-11$ & $30 \frac{9}{2}$ & CW and hydrided & 21.0 & 17.5 & 2.6 & $\sim 10,000$ & 17,900 & $\cdots$ & 47,000 & 7 & \\
\hline $60-11$ & $60 \%$ & $\mathrm{CW}$ and Hydrided & 21.0 & 20.0 & $\cdots$ & $\sim 15,000$ & 23,300 & $\cdots$ & - - & 7 & \\
\hline $\mathrm{K}-\mathrm{B}$ & & $\begin{array}{l}30 \% \mathrm{CW} \\
+ \text { Hydrided } \\
\text { and Irradiated }\end{array}$ & 15.0 & 14.5 & $0.5^{*}$ & 384 & -. & $\cdots$ & 10,101 & 7 & \\
\hline$K-D$ & & I & 12.0 & 11.5 & $1.5^{*}$ & $\cdots$ & -.. & $\ldots$ & 5 & 7 & \\
\hline
\end{tabular}

* Stress concentrator was an $1 / 8 \mathrm{in}$. wide slot milted into the oD surface to a depth equal

to $80 \%$ of the tube wall thickness. 

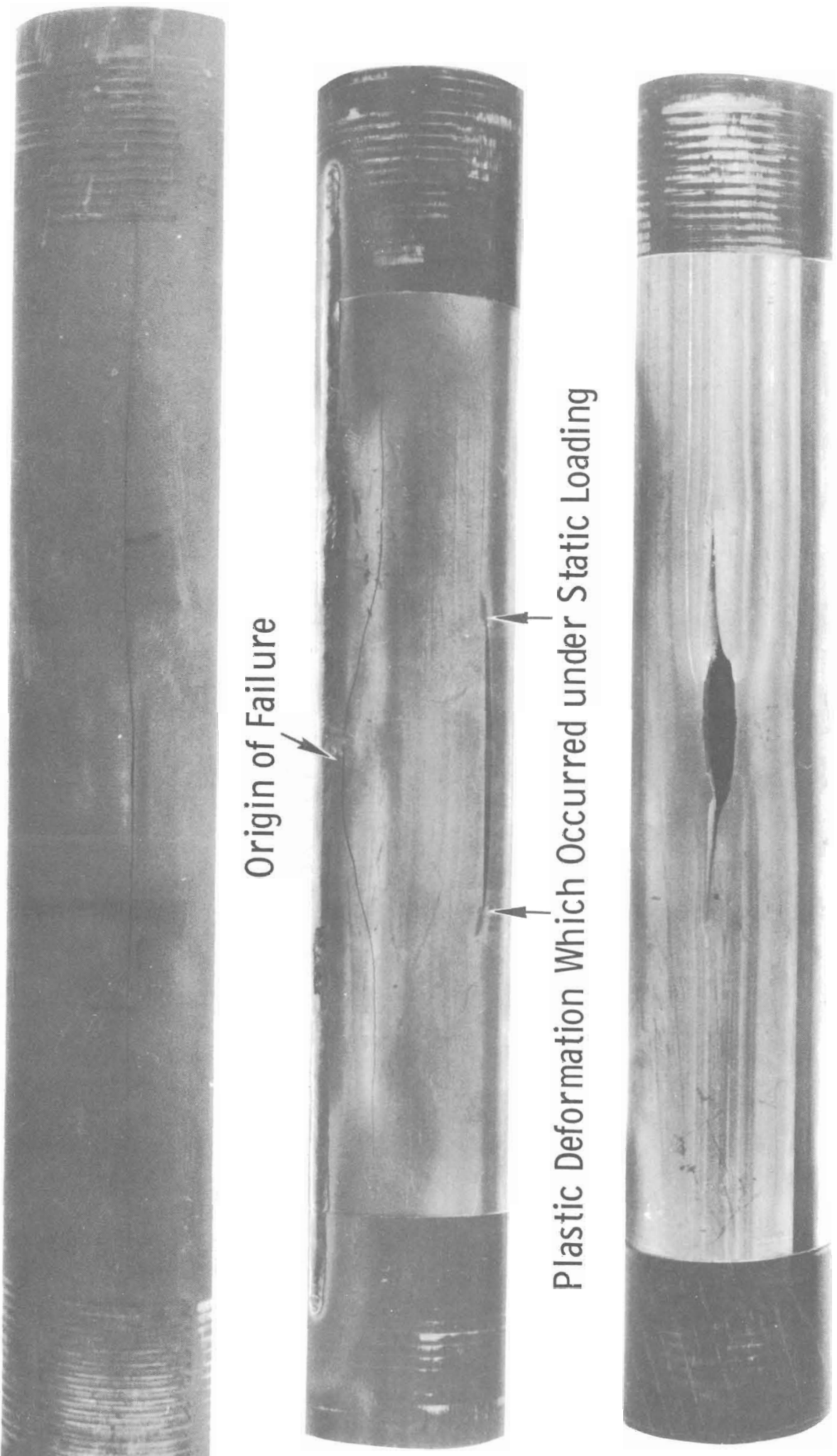

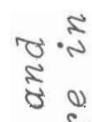

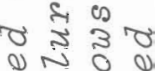

(1) N 007

0.0
4.45
4.45

० 4 \&

\& 40

$4 \sqrt{2}$
$4 \pi$

$n$ in

0
0

ब.

a 3

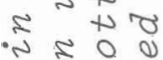

Uू

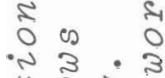

n 0 o

$\theta \leqslant 50$

ore.

5, 0

0.0 th

ह1

$\therefore<\vec{z}$

d) de do

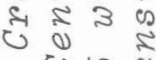

cus o n

- $n$ ह हु

es os

- $55 \pi N$

\&. .

4)

C EA 0

\& $Q$ \&

ชิ

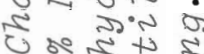

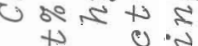

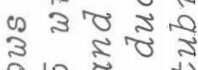

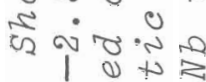

$\Omega_{1} \&_{1} \times c_{2}$

ON R " N 2

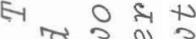

n o n n

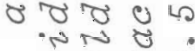

(1) \& 0 \&

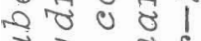

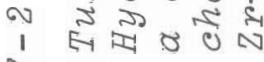

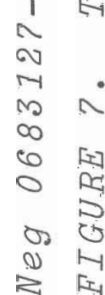


BNWL - 1076

unstable crack propagation formed from fatigue crack. After irradiation, however, the fracture toughness of hydrided tubing is little if any different from that of tubing in the heat treated, cold worked, aged, and hydrided condition. Higher neutron fluxes and exposures are needed to fully assess the effects of neutron irradiation.

UNUSUAL FRACTURES

For all of the tubing tested in the heat treated condition, at critical size the cracks nearly always propagated the full length of the test specimens. (See upper photograph of Figure 7.) Tubing in the cold worked condition, however, rarely exhibited "brittle" crack propagation from the tips of the growing fatigue crack. There were, however, some unusual fractures observed in these investigations.

An unusual fracture occurred in one cold worked test specimen after hydriding. This unusual fracture is shown in the center photograph of Figure 7 and in Figure 8. This test specimen had previously been used in a fracture test using a $1 / 8$ in. wide milled slot as the fracture initiator. After the specimen was welded in a dry box, it was pressure cycled until a 3 in. long fatigue crack was produced. The tube was then steadily pressurized until failure occurred. Some limited ductile tearing from the ends of the fatigue crack occurred (see Figure 7). Unstable fracture, however, initiated in the heat affected zone of the weld (see Figure 8). This crack propagated axially for a short distance in the heat affected zone and then turned out of the heat affected zone. The crack then again turned and ran parallel to the axis. This crack propagated nearly the full length of the tube.

An unusual fracture was also found to occur in one tube in which two parallel fatigue cracks were grown (see Figure 9). In this tube it appears that unstable fracture began at the 
BNWL - 1076

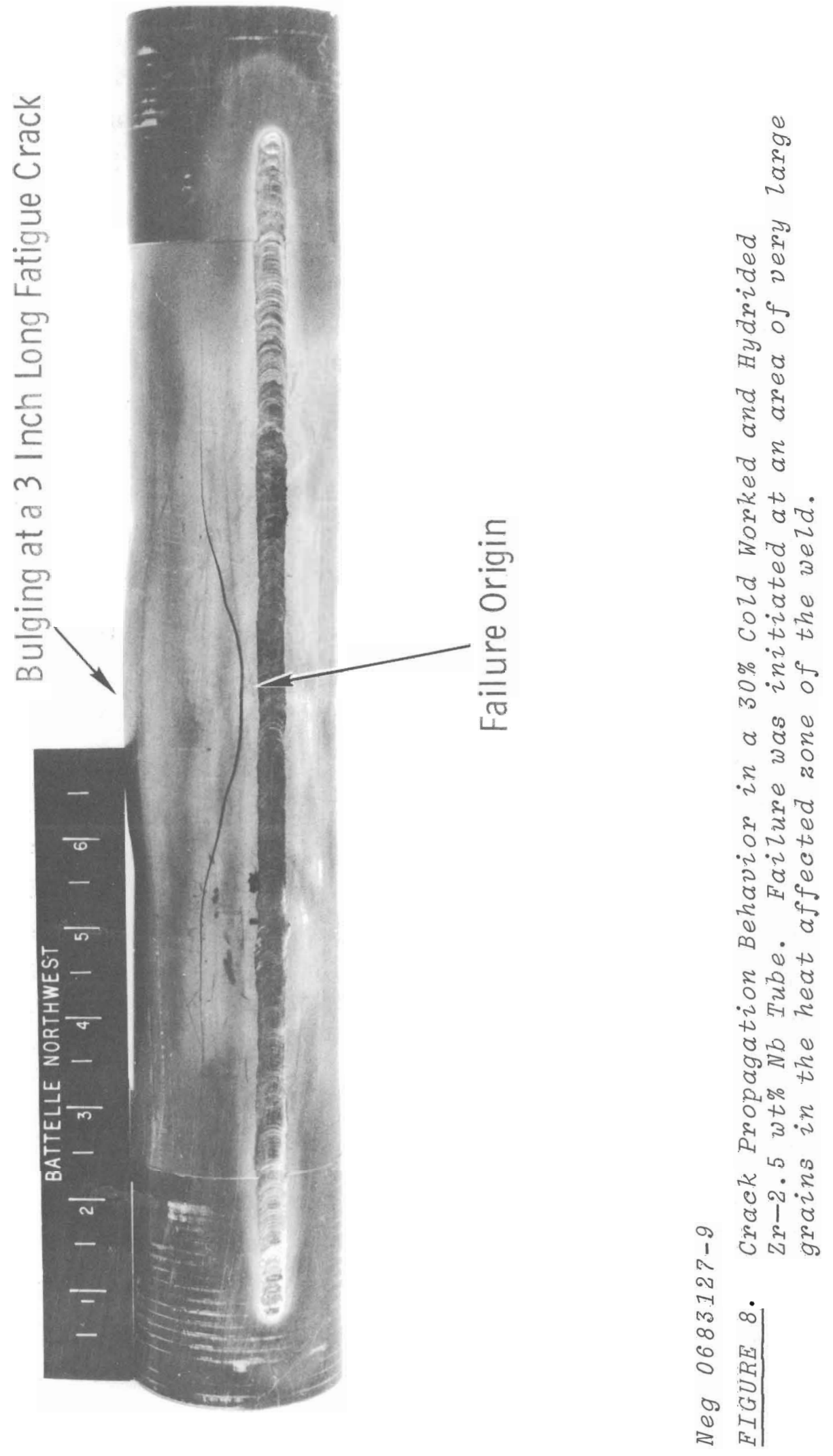


ends of the lower left fatigue crack. As the hoop stress on the crack propagating from the right end was relieved by the upper right fatigue crack and was arrested, unstable fracture began at the right end of the upper right fatigue crack. The length of either fatigue crack was slightly less than the minimum critical size for any of the tests in which a single fatigue crack initiated unstable fracture.

Neg 0683127-8

FIGURE 9. Crack Propagation Behavior in 2r-2.5 wt\% Nb Tube with Two Parallel slots

Another type of unusual fracture occurred in the $4.07 \mathrm{in}$. ID $\times 0.095$ in. wall thickness tubing (see Figure 10). For pressure cycling, these tubular test specimens were sealed with threaded end plugs, and the tube wall and plug fusion welded to effect the pressure seal. The function of the threads was to provide the necessary shear strength to keep the end plugs from blowing out. Clamping bands, somewhat wider than the thickness of the end plugs, were placed at each end to minimize flexing as the tube expanded during each pressure cycle. In the two instances, fatigue cracks formed in the thread relief and continued to grow circumferentially. For the tube shown in Figure 10, the circumferential crack propagated nearly the full circumference of the tube. Since the crack was under the clamping band, no growth or critical size measurements were obtained. This all occurred with little or no crack growth occurring at the axially aligned EDM slot. 


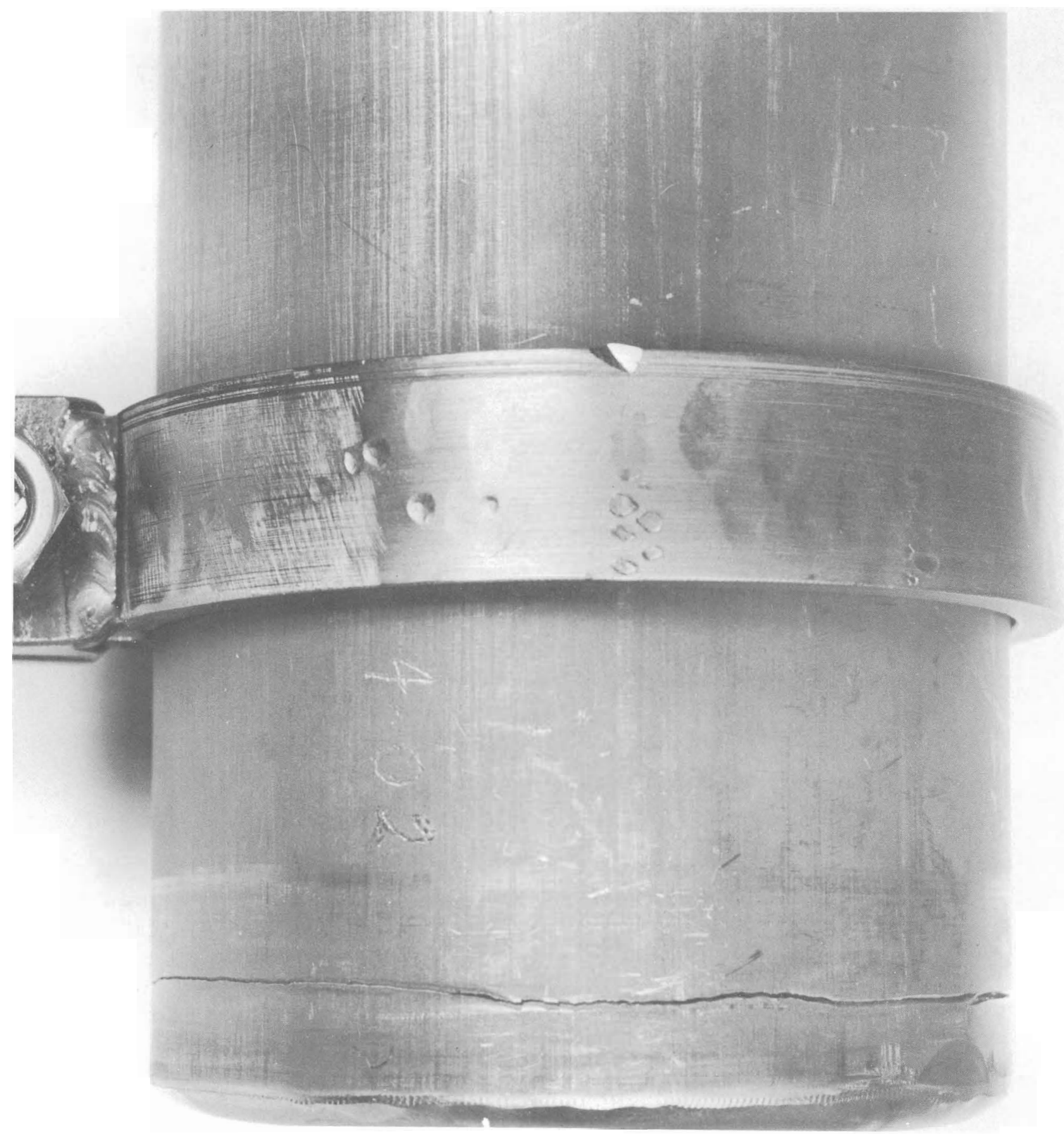

Neg $0690996-2$

FIGURE 10. A Circumferential Fatigue Crack at the Thread Relief in a Heat Treated and Hydrided $2 r-2.5$ wt\% Nb AlZoy Tube. [During pressure cycling the crack under the clamp (shown at left) grew while there was little or no growth at an axially aligned EDM slot at the midlength of the tube.] 


\section{REFERENCES}

1. W. J. O'Donnel and B. F. Langer. "Fatigue Design Basis for Zircaloy Components," Nucl. Sci. Eng., vol. 20, pp. 1-12. 1964

2. K. E. Hofer, Jr. "Equations for Fracture Mechanics," Machine Design, vol. 40, No. 3, pp. 109-113. February 1, 1968 .

3. T. J. Atterbury, et al. Investigations of the Initiation and Extent of Ductile Pipe Rupture, BMI-1793. Battelie Memorial Institute, Columbus, Ohio, January 1967.

4. E. S. Folias. An Axial Crack in a Pressurized Cylindrical Shell, ARL 64-174. Aerospace Research Laboratories, october 1964.

5. P. Paris and F. Erdogan. "A Critical Analysis of Crack Propagation Laws," J. Basic Eng. Trans. ASME, Series D, vol. 85, pp. 528-534. December 1963. 


\section{DISTRIBUTION}

No. of

Copies

\section{OFFSITE}

AEC Canoga Park

Canoga Park, California

RDT Site Office

AEC Chicago Patent Group

G. H. Lee

$\underline{\text { AEC Division of Technical Information Extension }}$

AEC, Germantown, Pennsylvania

DRDT, Technical Advisory Committee

N. E. Todreas, Office of Reactor Engineering

R. Feit, Office of Plant Engineering

R. M. Scroggins, Office of Reactor Technology

S. Strauch, Office of Program Analysis

A. Van Echo, Office of Reactor Technology

Assistant Genera1 Counse1 for Patents

R. A. Anderson

AEC Library, Washington, D.C. Division of Reactor Development Technology

Chief, HWOCR Branch (3)

Chief, Core Design Branch

Chief, Fuel Fabrication Branch

Chief, Control Mechanisms Branch

Assistant Director, Reactor Technology

Chief, Fuels and Materials Branch

Chief, Special Technology Branch

H. J. Reynolds

Atomic Energy of Canada Limited

E. C. W. Perryman

J.A. L. Robertson

P. A. Ross Ross

W. R. Thomas 
No. of

Copies

1

Babcock and Wilcox

Lynchburg, Virginia

M. W. Croft

1

Carolina-Nuclear Power Association

Parr, South Carolina

W. N. Thomas

1

3

1

du Pont Company, Savannah River

RDT Site Representative

3

du Pont Company, Savannah River Aiken, South Carolina

S. W. O'Rear (2)

D. F. Babcock

1

2

1

USAEC, Scientific Representative

Chalk River, Ontario Canada

R. W. Ramsey, Jr.

ONS I TE-HANFORD

1

AEC Chicago Patent Group

R. K. Sharp (Richland) 
No. of

Copies

3

1

3

6

21
AEC RDT Site Representative

P. G. Holsted (2)

A. S. Waterhouse

AEC Richland Operations Office

C. L. Robinson

Batte1le Memorial Institute

Douglas United Nuclear Corporation

W. K. Alexander

T. W. Ambrose

P. A. Carlson

R. Cooperstein

D. H. Curtiss

File

Batte11e-Northwest

F. W. Albaugh

R. C. Aungst

A. L. Bement

H. Harty

R. L. Knecht

T. R. Ostrom

P. J. Pankaskie (5)

E. B. Schwenk, Jr.

L. D. Turner

R. G. Wheeler

Technical Information Files (5)

Technical Publications (2) 